\title{
Effects of the harmful diatom Chaetoceros concavicornis on respiration of rainbow trout Oncorhynchus mykiss
}

\author{
C. Z. Yang, L. J. Albright \\ Institute for Aquaculture Research, Department of Biological Sciences, Simon Fraser University, Burnaby, British Columbia, \\ Canada V5A 1 S6
}

\begin{abstract}
Chaetoceros concavicornis and C. convolutus are harmful diatom species which commonly occur in many temperate coastal marine waters and which can cause finfish mortalities when present at concentrations as low as 5 cells $\mathrm{ml}^{-1}$ of seawater. Death of finfish, including salmonids, by these harmful Chaetoceros spp. has been suggested to be caused by: (1) microbial infections of damaged gill tissue; (2) hemorrhage of gill capillaries; or (3) suffocation from excess mucus production at the sites of penetration of the gills by the spines. Our data indicate that the barbed spines of these diatoms damage the physical integrity of the respiratory epithelium of rainbow trout Oncorhynchus mykiss. The trout responds to this physical impairment of gill tissue by producing excessive amounts of mucus. The accumulation of this mucus on and between the secondary lamellae inhibits the gill function of $\mathrm{O}_{2}$ uptake (and likely metabolic waste products release). The hypoxic conditions which result within the fish then cause a cascade of events, including anaerobic metabolism. Trout mortalities occur coincident with severe decreases in $\mathrm{O}_{2}$ concentration and $\mathrm{pH}$ as well as increases in lactate and glucose concentrations of the arterial blood.
\end{abstract}

\section{INTRODUCTION}

Chaetoceros concavicornis and C. convolutus are harmful diatom species which commonly occur in many temperate coastal marine waters, including those of British Columbia (Albright et al. in press), and which can cause finfish mortalities when they are present in sufficient concentrations. As few as 5 cells of these harmful Chaetoceros spp. per ml of seawater can kill salmonids (Bell et al. 1974). And, because harmful Chaetoceros spp. which exceed these concentrations often occur in the surface marine waters of coastal British Columbia (Albright et al. in press), many penned salmon have been killed by these phytoplankters (Bell et al. 1974, Kennedy et al. 1976, Brett et al. 1978). These chainforming, 'bullet-shaped' cells have hollow spines (setae) extending from their corners. The spines are studded with much smaller spines (spinules) along their length. Apparently, the spines break off and penetrate the (fish) gill membranes butt end first. The spinules are directed toward the tip of the spine, thus preventing the setae from coming out (Gaines \& Taylor 1986).
Death of finfish by these harmful Chaetoceros spp. has been suggested to be caused by (1) microbial infections of damaged gill tissue; (2) hemorrhage of gill capillaries; or (3) suffocation from excess mucus production at the sites of penetration of the gills by the spines (Bell 1961)

Within as little as $48 \mathrm{~h}$ of the onset of a harmful Chaetoceros spp. bloom, mortalities of penned salmonids can occur. Because of this very short period of time between the appearance of harmful concentrations of diatoms and the onset of mortalities, the latter 2 of the above listed possibilities appear to be the most likely causes of death. If this is so, the impairment of gill function in salmonids affected by the harmful Chaetoceros spp. should cause significant changes in the fishes' oxygen transport system. This study was therefore initiated to study the effects of harmful concentrations of $C$. concavicornis on the oxygen transport system, such as changes of gill lamellar structure, arterial blood oxygen tension, ventilation volume and frequency and $\mathrm{pH}$ values of arterial blood and erythrocytes of rainbow trout Oncorhynchus mykiss. 


\section{MATERIALS AND METHODS}

Fish. All experiments were carried out using 180 to $336 \mathrm{~g}$ rainbow trout Oncorhynchus mykiss, which were obtained from a commercial trout farm. All fish were transported to Simon Fraser University and placed in $20 \%$ salinity water at least $15 \mathrm{~d}$ prior to cannulation. The oxygen concentrations, $\mathrm{pH}$ values and temperatures of the dilute seawater in which the fish were placed varied from 8.3 to $9.7 \mathrm{mg} \mathrm{ml}^{-1}, 7.2$ to 8.0 units and 14 to $16^{\circ} \mathrm{C}$ respectively. Feeding was discontinued $7 \mathrm{~d}$ prior to cannulation.

Anesthesia and surgical procedures. While held immobile in a net, each fish was anesthetized by immersion in neutralized tricaine methanesulfonate (MS 222, $0.1 \mathrm{~g}^{-1}$ ) for ca $4 \mathrm{~min}$. Following this treatment, the gills were perfused with oxygenated water containing a small amount of MS $222\left(0.05 \mathrm{~g} \mathrm{l}^{-1}\right)$ by means of a recirculating pump. Throughout the subsequent surgical procedures, cooling the recirculating water to $5-6^{\circ} \mathrm{C}$ greatly extended the period for which the fish could be maintained under anesthesia.

While under anesthetic the fish were cannulated at the following sites:

(1) Buccal cavity. One of the nasal openings was enlarged using a no. 16 needle (Saunders 1962). Eighty $\mathrm{cm}$ of PE 90 polyethylene tubing was immediately passed through this hole. The end of the tubing was then heat-flared to anchor it on the inside of the mouth and cotton thread was wrapped around the tubing where it emerged from the nasal opening to prevent inward movement of the cannula.

(2) Opercular cavity. A hole was punched in the centre of one operculum with a no. 16 needle, and 80 $\mathrm{cm}$ of heat-flared, PE 90 polyethylene tubing was anchored in the hole as described above.

(3) Dorsal aorta. This vessel was cannulated using a modification of the method of Soivio et al. (1975). The cannulas were prepared from PE 50 polyethylene tubing. A steel wire $(0.5 \mathrm{~mm}$ diameter $)$ with the tip filed to a sharp point was inserted in the cannula. Before the operation the cannula was filled with $\mathrm{Na}$-heparinate (Sigma), $200 \mathrm{IU} \mathrm{ml} \mathrm{m}^{-1}$ in isotonic $(1 \%) \mathrm{NaCl}$ solution. The tip of the steel wire and cannula were pushed through one of the nasal openings and then inserted into the blood vessel at the point between the first and second gill arches. Following insertion, the cannula was then pushed into the aorta until blood exited from the distal end of the cannula. The steel wire was then pulled out while the cannula was held in place in. the aorta. The nearer end of the cannula was then pulled out through one of the nasal openings and fixed on the dorsal fin. The end was stoppered with a no. $231 / 2$ gauge needle and a $1 \mathrm{ml}$ disposable syringe.

Experimental procedure. Following cannulation, each of 14 fish was placed in a metabolic chamber described by Maren et al. (1968). The chambers were then placed in four $75 \times 60 \times 22 \mathrm{~cm}$ black boxes: 8 chambers in the first 2 boxes containing treated fish , 6 in the other 2 boxes containing untreated control fish. Seawater of $20 \%$ salinity was recirculated through each chamber; the seawater was changed once each day. The $\mathrm{pH}$ and temperature of the recirculated waters varied between 7.3 and 8.0 units and 14 and $16^{\circ} \mathrm{C}$ respectively. The oxygen partial pressure was $>130 \mathrm{~mm} \mathrm{Hg}$ during the course of the experiments. Following cannulation, the fish were allowed to recover for $48 \mathrm{~h}$ in the respiration chambers. During this recovery time the aortic cannulas were flushed once daily with the heparized saline.

Forty-eight hours after cannulation, Chaetocerous concavicornis was added to the sea water of the first 2 boxes at a concentration of ca 50 cells $\mathrm{ml}^{-1}$. The fish were sampled for all experimental parameters immediately prior to exposure to $C$. concavicornis.

Analytic techniques. Arterial blood $\mathrm{pH}$ was measured using a Radiometer G 2971 G2 electrode in a thermostated cuvette and recorded using a Radiometer PHM 73 meter. Arterial blood oxygen tension $\left(P \mathrm{a}_{\mathrm{O}_{2}}\right)$, inspired water oxygen tension $\left(\mathrm{Pi}_{\mathrm{O}_{2}}\right)$, and expired water oxygen tension $\left(P_{\mathrm{O}_{2}}\right)$ were measured using a Radiometer E 5046/0 electrode in a thermostated cuvette and recorded using a PHM 73 meter. The meter was calibrated prior to each $P_{\mathrm{O}_{2}}$ measurement. The electrode was exposed to humidified $\mathrm{N}_{2}$ prior to the determination of $\mathrm{PaO}_{2^{\prime}} \mathrm{Pi}_{\mathrm{O}_{2}}$ and $P_{\mathrm{O}_{2}}$ to improve response time and decrease hysteresis, as recommended by Moran et al. (1966).

Haematocrit values. These were determined by the microcapillary method.

Plasma lactate and glucose concentrations. These were determined spectrophotometrically using Sigma diagnostic kits.

Light and scanning electron microscopy. At the end of each experiment, branchial arches were removed from randomly selected treated and control trout and washed in a $1.1 \%$ saline solution. Parts of these washed gills were then fixed in Davidson's solution, dehydrated in ethanol, impregnated with wax, sectioned, stained with hemotoxylin and eosin and examined by light microscopy. Parts of the gills were fixed in glutaraldehyde, post-fixed in $1 \% \mathrm{OsO}_{4}$, dehydrated in ethanol and amyl acetate, critical-point dried and then coated with gold. These samples were examined using an Autoscan scanning electron microscope.

Determination of oxygen consumption. After the respiratory chamber was sealed with rubber stoppers, water within the chamber was sampled immediately (time $=t_{0}$ ) using a needle punched through each stop- 
per. The oxygen tension $\left(\mathrm{P}_{\mathrm{O}_{2}}\right)$ at $t_{0}$ was determined using a Radiometer E 5046/0 electrode. At intervals of 5 min thereafter, oxygen tensions were determined in a similar manner. These data were used to determine the rate of decrease of oxygen tension in the water. Following each experiment, the weight of each fish was determined and its volume was measured. The volume of each respiratory chamber was also measured. These values were used to determine the specific rate of oxygen consumption ( $\mathrm{mg} \mathrm{O} \mathrm{O}_{2} \mathrm{~kg}^{-1} \mathrm{~h}^{-1}$ ) of each trout.

Determination of ventilation volume. Ventilation volume was calculated by the Fick principle (Guyton 1981) using the following equation:

$$
V_{\mathrm{g}}=V_{\mathrm{O}_{2}} /\left(P \mathrm{i}_{\mathrm{O}_{2}}-P \mathrm{e}_{\mathrm{O}_{2}}\right) a_{\mathrm{O}_{2}}
$$

where $V_{\mathrm{g}}=$ ventilation volume $\left(\mathrm{ml} \mathrm{min} \mathrm{min}^{-1} \mathrm{~kg}^{-1}\right)_{i} V_{\mathrm{O}_{2}}=$ $\mathrm{O}_{2}$ uptake ( $\left.\mathrm{ml} \mathrm{min}{ }^{-1} \mathrm{~kg}^{-1}\right) ; a_{\mathrm{O}_{2}}=$ solubility coefficient of oxygen in water $\left(\mathrm{ml} \mathrm{m} \mathrm{m}^{-1} \mathrm{~mm} \mathrm{Hg}\right) ; P=$ partial pressure of gas ( $\mathrm{mm} \mathrm{Hg}$ ); and the subscripts $i$ and $e$ refer to water in the buccal cavity (inspired) and opercular cavity (expired) respectively.

Determination of intracellular $\mathrm{pH}$. Red blood cells obtained by centrifuging $600 \mu \mathrm{l}$ of blood at $20000 \times \mathrm{g}$ for $5 \mathrm{~min}$ were frozen to $-20^{\circ} \mathrm{C}$, thawed for $5 \mathrm{~min}$ and refrozen to $-20^{\circ} \mathrm{C}$. To prevent the acid shift observed when lysed samples remain unfrozen, measurements of intracellular $\mathrm{pH}\left(\mathrm{pH}_{\mathrm{i}}\right)$ were made immediately after the second thawing using a Radiometer G 2971 G2 electrode in a thermostated cuvette and recorded using a Radiometer PHM meter.

Statistical analyses. Values are expressed as the arithemitic mean \pm standard error (SE). All comparisons between treated and control fish were made by 1 way analysis of variance.

\section{RESULTS}

The mean concentration of Chaetoceros concavicornis cells remained between 51 and 58 cells $\mathrm{ml}^{-1}$ during the $72 \mathrm{~h}$ course of the experiments described below (Fig. 1).

The inter-secondary lamellar spaces of the trout quickly accumulated a compact mass of Chaetoceros concavicornis cells (Fig. 2A). And, some of the spines of these diatoms appeared to penetrate the lamellar cells (Fig. 2B). Coincident with this entrapment of diatoms in the inter-secondary lamellar spaces and the apparent penetration of the cells with the barbed spines, there was an accumulation of mucus-like material on the surfaces of the secondary lamellae (Fig. 2C); indeed, in some cases, a mass of $C$. concavicornis and what appeared to be mucus filled the volumes between many adjacent secondary lamellar cells (Fig. 2D). The mucous cells of the secondary lamellae of treated trout

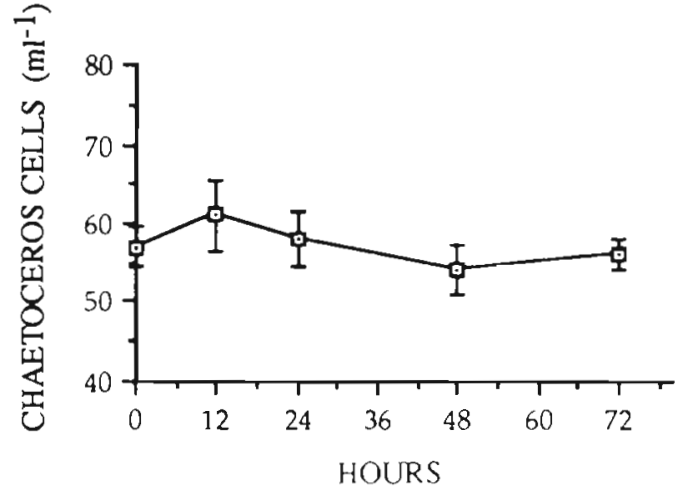

Fig. 1. Concentration of Chaetoceros concavicornis cells in the treated seawater

were more numerous and more prominent than those of this organ in untreated control trout.

Histological examination of gills of fish treated with Chaetoceros concavicornis showed hyperplasia, hypertrophy and partial and complete fusion of secondary lamellae (Fig. 3A). The fish also showed severe edema, collapsed pillar cell systems, detachment of epithelial cells from the walls of the blood capillaries and localized hemorrhaging of some secondary lamellae (Fig. 3B) in comparison to the lamellar cells of untreated fish (Fig. 3C).

The mean $P_{\mathrm{O}_{2}}$ of the blood sampled from the dorsal aorta of the treated fish decreased from ca $100 \mathrm{~mm} \mathrm{Hg}$ to ca $50 \mathrm{~mm} \mathrm{Hg}$ over a $72 \mathrm{~h}$ period when the fish were treated with water containing between 51 and 58 cells $\mathrm{ml}^{-1}$ of Chaetoceros concavicornis (Fig. 4). The mean $P_{\mathrm{O}_{2}}$ of blood sampled from the dorsal aorta of the control fish untreated with $C$. concavicornis remained approximately the same over the $72 \mathrm{~h}$ period (Fig. 4). The $P_{\mathrm{O}_{2}}$ difference between treated and control fish was significant $(\mathrm{p}<0.001)$.

The mean $\mathrm{pH}$ of the dorsal aorta blood $\left(\mathrm{pH}_{\mathrm{a}}\right)$ of fish decreased from 7.81 to 7.64 following Chaetoceros concavicornis treatment for $72 \mathrm{~h}$ while the mean $\mathrm{pH}$ of the untreated control fish remained relatively constant at 7.77 to 7.83 (Fig. 5).

The mean ventilation volume of treated fish increased significantly ( $p<0.001)$ to 3666 from $1258 \mathrm{ml}$ $\mathrm{kg}^{-1} \mathrm{~min}^{-1}$ during the $72 \mathrm{~h}$ exposure to Chaetoceros concavicornis, while the mean ventilation volume of the untreated control fish remained within the range of 1211 to $1298 \mathrm{ml} \mathrm{kg}^{-1} \mathrm{~min}^{-1}$ during this same time period (Fig. 6). The difference is significant.

The mean ventilation frequency of treated fish increased to 131 from 79 times $\mathrm{min}^{-1}$ following a $72 \mathrm{~h}$ exposure to Chaetoceros concavicornis (Fig. 7). The mean ventilation frequency of the control fish remained within the range of 71 to 81 times $\min ^{-1}$ (Fig. 7). The ventilation frequency difference between treated and control fish was significant $(p<0.005)$. 


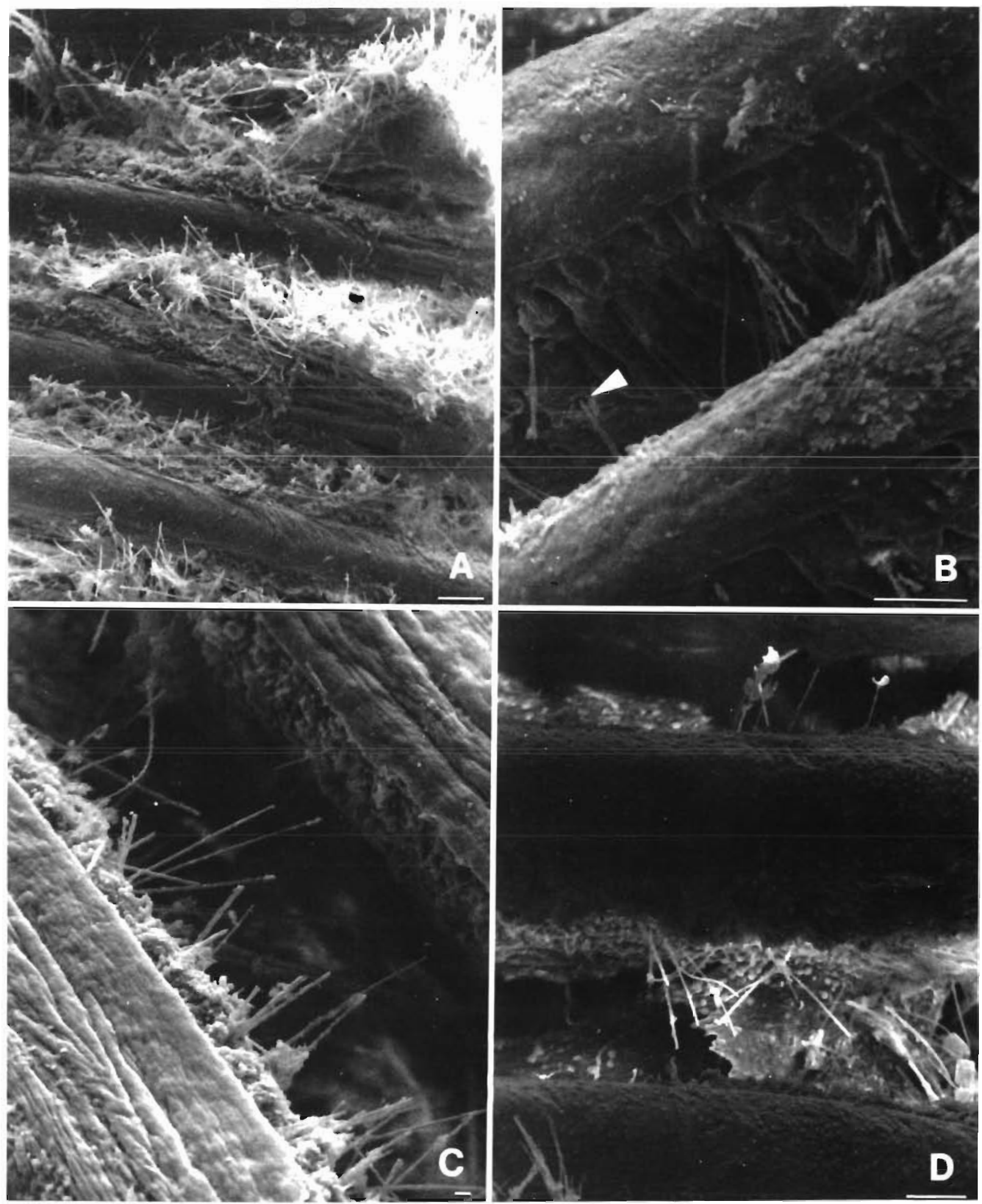

Fig. 2. Chaetoceros concavicornis on gill tissue of Oncorhynchus mykiss. Scanning electron microscopic views of: (A) $C$. concavicornis between secondary lamellae; (B) penetration of lamellar cells by spines; (C) accumulation of mucus on lamellar cells and (D) inter-secondary lamellar accumulations of C. concavicornis cells and mucus-like material. Scale bars are $100 \mu \mathrm{m}$ in (A), (B) and (D), $10 \mu \mathrm{m}$ in $(\mathrm{C})$ 
Fig. 3. Oncorhynchus mykiss exposed to Chaetoceros concavicornis. Light microscopic views of: (A) gill lamellae of C. Concavicornis treated rainbow trout; note hyperplasia, partial and complete fusion of the secondary lamellae. $\mathrm{H}$ \& $\mathrm{E}$ staining, $150 x_{i}$ (B) gill lamellae of $C$ concavicornis treated rainbow trout; note severe edema, collapsed pillar cells, hemorrhaging (arrowhead) and detachment of the secondary lamellae. $H \& E$ staining, $240 x_{\text {; }}$ (C) gill lamellae of untreated rainbow trout. $\mathrm{H} \& \mathrm{E}$ staining, $150 \times$
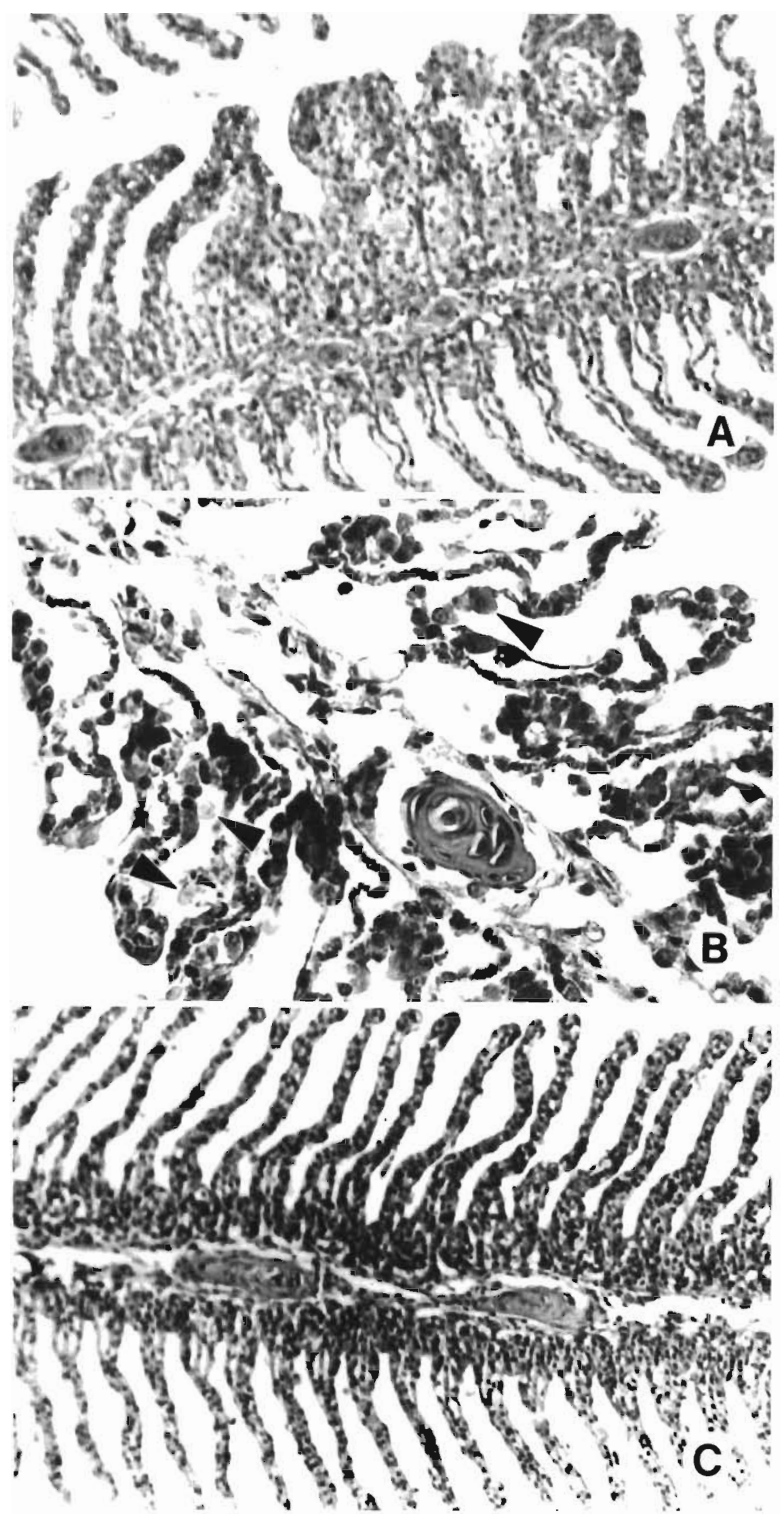


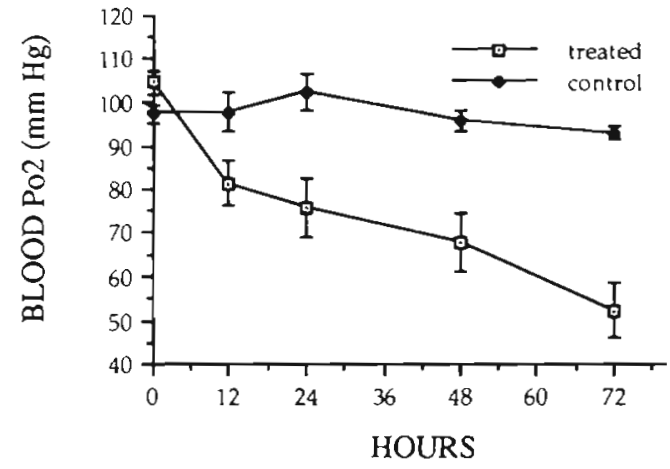

Fig. 4. Oncorhynchus mykiss treated with Chaetoceros concavicornis cells. Partial pressure of oxygen in the dorsal aorta blood of trout

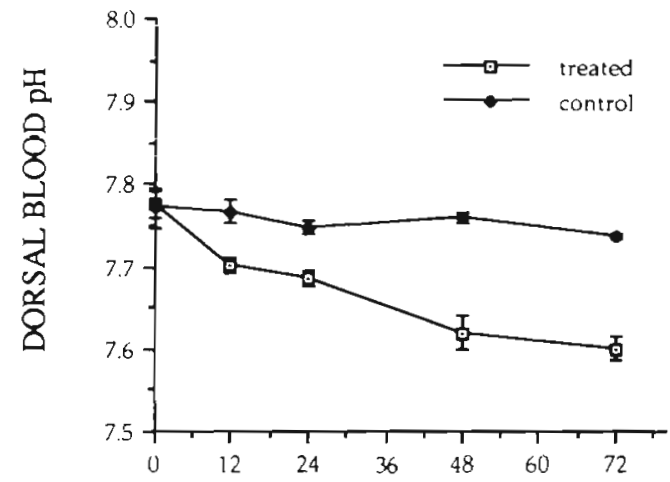

HOURS

Fig. 5. Oncorhynchus mykiss treated with Chaetoceros concavicornis cells. Dorsal aorta blood $\mathrm{pH}_{a}$ of trout

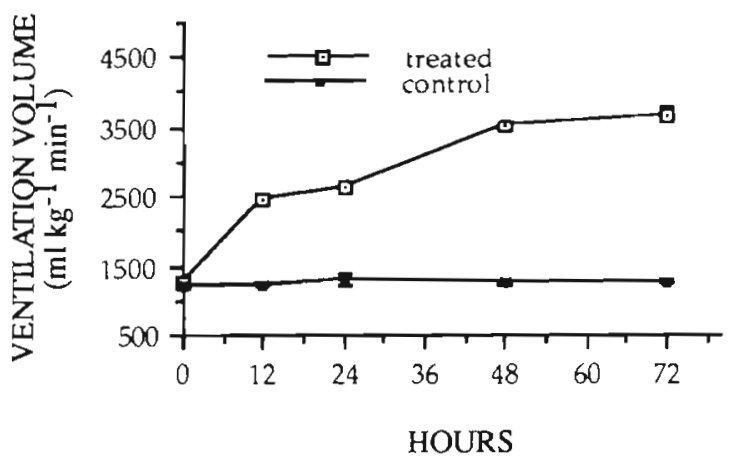

Fig. 6. Oncorhynchus mykiss treated with Chaetoceros concavicornis cells. Ventilation volume of trout

The mean $\mathrm{O}_{2}$ consumption of treated fish decreased from 95 to $88 \mathrm{mg} \mathrm{kg}^{-1} \mathrm{~h}^{-1}$ following a $72 \mathrm{~h}$ exposure to Chaetoceros concavicornis (Fig. 8). The mean $\mathrm{O}_{2}$ consumption of the untreated control fish remained within the range 93 to $97 \mathrm{mg} \mathrm{kg}^{-1} \mathrm{~h}^{-1}$ (Fig. 8). There was no significant difference between the $\mathrm{O}_{2}$ consumption of the treated and untreated fish during the first $12 \mathrm{~h}$ (Fig. 8). However, there was a significant difference

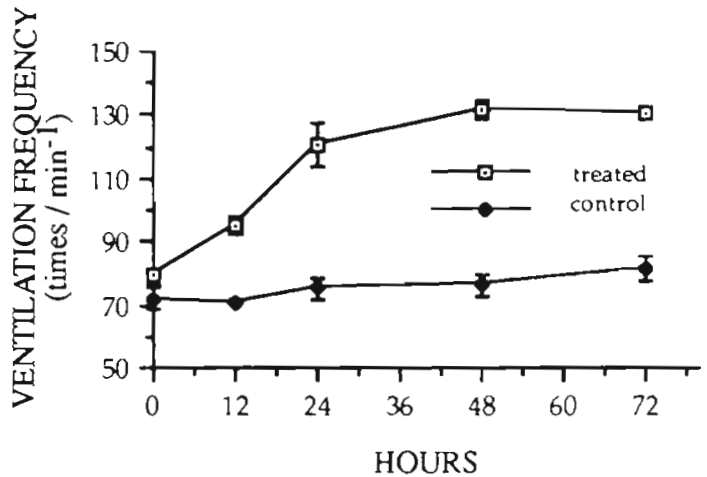

Fig. 7. Oncorhynchus mykiss treated with Chaetoceros concavicornis cells. Ventilation frequency of trout

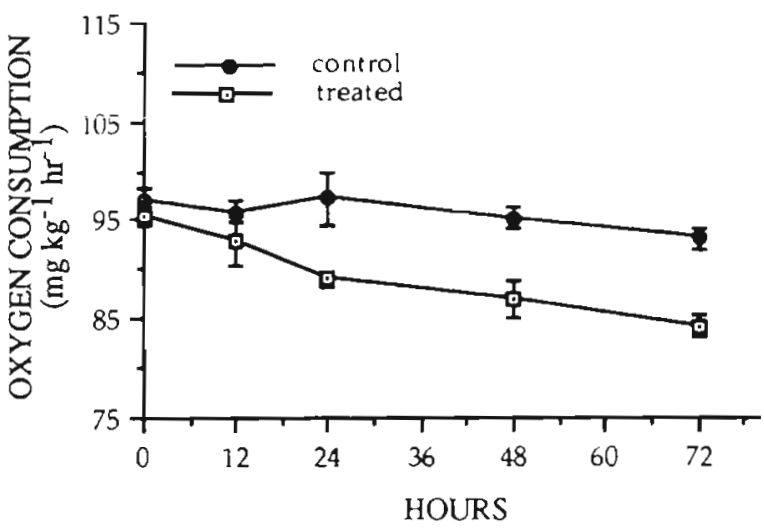

Fig. 8. Oncorhynchus mykiss treated with Chaetoceros concavicornis cells. Oxygen consumption of trout

between the $\mathrm{O}_{2}$ consumption of the treated and untreated fish following the first $12 \mathrm{~h}(\mathrm{p}<0.05)$.

Twelve hours after exposure to Chaetoceros concavicornis the mean haematocrit value increased to ca $22.1 \%$ from ca $18.9 \%$ (the value of the control fish at $12 \mathrm{~h}$ was ca $18.8 \%$ (Fig. 9). There was a significant difference between the values for the treated and untreated trout $(p<0.001)$.

The mean lactate concentration of the blood of the treated trout increased to $36.9 \mathrm{mg} 100 \mathrm{ml}^{-1}$ following Chaetoceros concavicornis treatment for $72 \mathrm{~h}$ in comparison to a value of $25.0 \mathrm{mg} 100 \mathrm{ml}^{-1}$ prior to treatment (Fig. 10). The mean concentration of lactate in the blood of the untreated control trout remained approximately the same during the $72 \mathrm{~h}$ of the experiment (Fig 10). There was a significant difference between the lactate concentrations of the blood of treated and untreated trout $(p<0.005)$.

The mean glucose concentration of trout blood increased to $60.9 \mathrm{mg} 100 \mathrm{ml}^{-1}$ following a $72 \mathrm{~h}$ treatment with Chaetoceros concavicornis (Fig. 11); the mean glucose concentration of these trout prior to $C$.

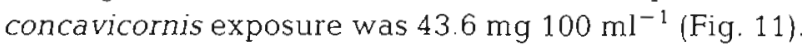




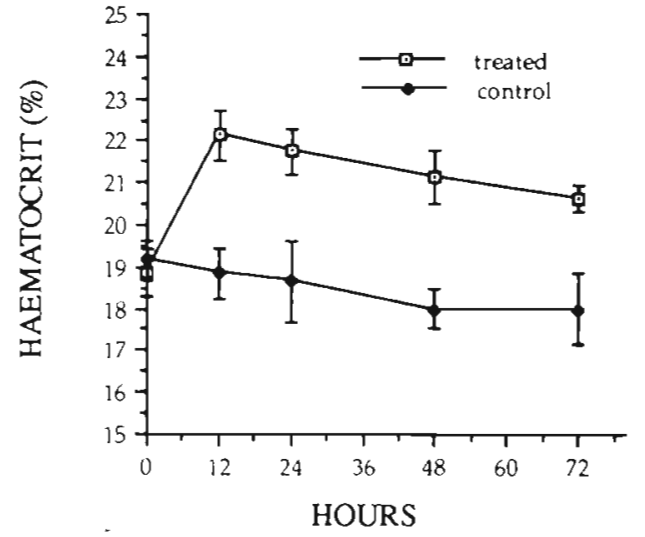

Fig. 9. Oncorhynchus mykiss treated with Chaetoceros concavicornis cells. Haematocrit of trout

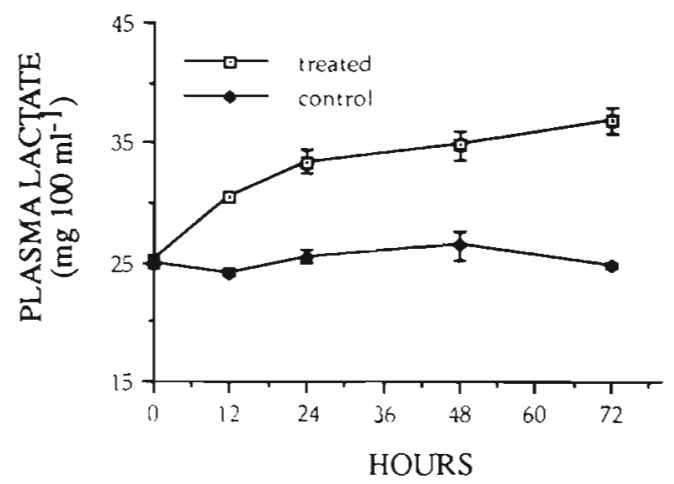

Fig. 10. Oncorhynchus mykiss treated with Chaetoceros concavicornis cells. Blood lactate concentrations of trout

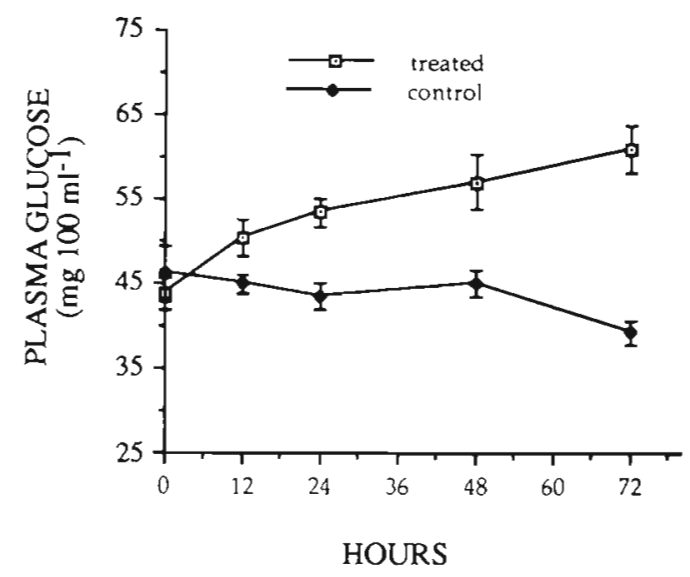

Fig. 11. Oncorhynchus mykiss treated with Chaetoceros concavicornis cells. Blood glucose concentrations of trout

The mean concentration of blood glucose of the untreated fish remained between 46.2 and $39.3 \mathrm{mg}$ $100 \mathrm{ml}^{-1}$. There was a significant difference between the blood glucose concentrations of the treated and control trout $(p<0.005)$.

The mean erythrocyte $\mathrm{pH}_{1}$ of the treated fish

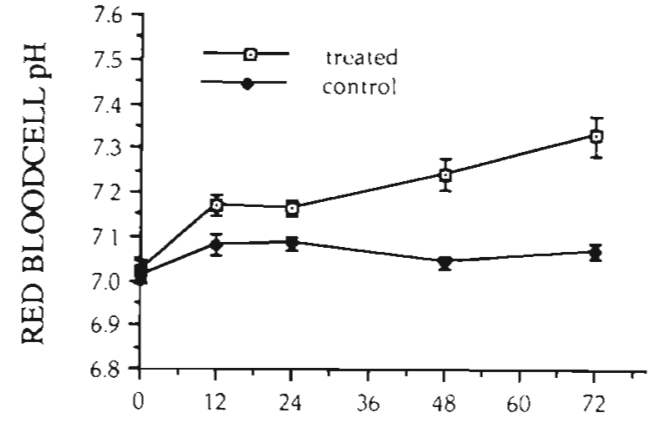

HOURS

Fig. 12. Oncorhynchus mykiss treated with Chaetoceros concavicornis cells. Intracellular erythrocyte $\mathrm{pH}\left(\mathrm{pH}_{\mathrm{i}}\right)$ of trout

increased from 7.02 prior to treatment to 7.33 following Chaetoceros concavicornis treatment for $72 \mathrm{~h}$ (Fig. 12). The mean $\mathrm{pH}_{1}$ values of the control fish varied from 7.01 to 7.09 during the $72 \mathrm{~h}$ of the experiment (Fig. 12).

\section{DISCUSSION}

Scanning electron micrographs clearly showed that Chaetoceros concavicornis cells and their barbed spines become wedged in the inter-secondary lamellar spaces of these fish to form what appears to be 'windrow-like' masses of immobilized diatoms and their broken spines (Fig. 2A). Many of the spines have broken off the diatom frustules and some appear to have penetrated the lamellar cells (Fig. 2B). A careful examination of these micrographs (especially Fig. 2C, D) and those of Fig. 3 indicates that the cells of this tissue appear to respond to this injury in several ways. One of the responses is the formation of what appears to be excessive amounts of mucus on and between the secondary lamellae of the treated fish (Fig. 2C, D). A histological analysis of this tissue further showed that many of these lamellar cells underwent hypertrophy and hyperplasia $72 \mathrm{~h}$ after $C$. concavicornis treatment (Fig. 3). These observations cannot be used to determine the sequence of events which occur upon exposure of these trout lamellae to harmful concentrations of C. concavicornis. Nevertheless, it would appear likely that the production of mucus would be initiated first, followed by cell hyperplasia. Cell hypertrophy may occur coincident with or following the initiation of mucus production.

We observed a small amount of hemorrhage of secondary lamellae (Fig. 3C) but did not observe any overt signs of secondary infections caused by Chaetoceros concavicornis during the $72 \mathrm{~h}$ of this experiment, both 
of which processes were suggested by Bell (1961) to be mechanisms by which $C$. concavicornis may cause death of affected finfish.

Based upon the above observations, it appears that the production of excess mucus, hypertrophy and hyperplasia of the respiratory epithelium cells of the trout, caused by exposure to this harmful phytoplankter, will physically limit gill functions, including gaseous and waste product exchange at the interface of secondary lamellar cells within the aqueous environment. The reduced oxygen-diffusing capacity of the gills in particular would in turn initiate a cascade of events in the respiratory chain of the trout. One would therefore predict changes to functions such as aortal blood $\mathrm{O}_{2}$ pressure and $\mathrm{pH}$, ventilation volumes and frequencies, plasma lactate and glucose concentrations, haematocrit and erythrocyte $\mathrm{pH}_{\mathrm{i}}$.

The effects of environmental hypoxia on respiratory gas transpurt in teleost fishes have been studied extensively, and adaptational responses have been found in the respiratory chain including changes in arterial

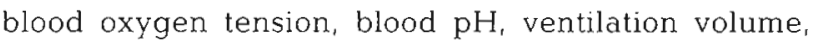
ventilation frequency and $\mathrm{O}_{2}$ consumption (Holeton \& Randall 1967a, Randall 1982). Specific responses of the various portions of the trout respiratory transport system as they relate to exposure to Chaetoceros concavicornis are discussed below.

The continuous depletion of $\mathrm{O}_{2}$ with time from arterial blood in Chaetoceros concavicornis treated fish (Fig. 4) probably is directly caused by diffusion limitation at the secondary lamellae due to excess mucus production. This reduction in arterial $\mathrm{O}_{2}$ pressure then affects the trout's ventilation volumes and frequencies. Smith \& Jones (1982) have shown an effect similar to the one noted herein, where they found that a reduction of blood oxygen pressure by hypoxia in rainbow trout stimulated the animal's ventilation volume. Similar effects have been noted by Randall \& Jones (1973) and Holeton \& Randall (1967a).

Under hypoxic conditions the fish attempts to maintain its blood $\mathrm{O}_{2}$ at required concentrations by increasing both its ventilation volumes and frequencies, the actual values varying with the species (Smith \& Jones 1982). Holeton \& Randall (1967b) found that rainbow trout ventilation frequency increased from ca 80 to $\mathrm{ca}$ $120 \mathrm{~min}^{-1}$ with advanced hypoxia. In our experiments, although the ventilation frequencies of the control trout varied between 70 and $80 \mathrm{~min}^{-1}$, the Chaetoceros concavicornis treated trout had frequencies in excess of $130 \mathrm{~min}^{-1}$ (Fig. 7), indicative of acute hypoxia.

The approximately $0.2 \mathrm{pH}$ increase in acidity of the blood within ca $24 \mathrm{~h}$ of exposure of the trout to Chaetoceros concavicornis could involve several factors, e.g. a change in plasma ionic composition and/or an increase in plasma metabolic acids. Following hypoxia, $\mathrm{H}^{+}$is believed to be extruded from erythrocytes, triggered by the release of catecholamines to the circulation which in turn stimulates $\mathrm{Na}^{+} / \mathrm{H}^{+}$exchangers located in their membranes. This has been shown in vitro for adrenaline-treated (Nikinmaa 1982) and isoproterenol-treated (Nikinmaa \& Huestis 1984) erythrocytes of rainbow trout. Nikinmaa (1982) and Cossins \& Richardson (1985) suggested that the $\mathrm{H}^{+}$extrusion could increase the hemoglobin oxygen affinity via the alkalization of the intracellular $\mathrm{pH}$. The increase of lactate levels in blood reported herein may be associated with the decrease in $\mathrm{pH}$. Tetens \& Lykkeboe (1985) reported lower blood $\mathrm{pH}$ after fish were exposed to hypoxic conditions. They suggested that the decreased $\mathrm{pH}$ in the blood was possibly caused by a release to the circulation of protons from muscle lactate.

Hypoxia of rainbow trout can cause metabolic acidification of the blood (Thomas \& Hughes 1982). In addition, the $\mathrm{pH}_{\mathrm{i}}$ increase (Fig. 12) and $\mathrm{pH}_{\mathrm{a}}$ decrease (Fig. 5) noted in our experiments are consistent with what has been observed in other experiments with teleosts undergoing hypoxia (Thomas \& Hughes 1982, Claireaux et al 1983, Fievet et al. 1988).

The very rapid increase in haematocrit values of dorsal aorta blood within $12 \mathrm{~h}$ of Chaetoceros concavicornis treatment may have been due to division of erythrocytes (Murad et al. 1990) and/or elevation of plasma catecholamine levels of the fish which could induce swelling of erythrocytes, entry of erythrocytes in to the circulatory system from storage organs, such as the spleen, and plasma skimming under the influence of hypoxia (Ostroumova 1964, Johansen \& Hanson 1967, Stevens 1968, Hughes 1981, Milligan \& Wood 1986, Ishimatsu et al 1988). Whatever the reason, the increased haematocrit concentrations observed in the present study were typical of those observed when teleost fish undergo hypoxia.

Lactate and glucose concentrations have been shown by many investigators to be sensitive indicators of hypoxic stress in rainbow trout (e.g. Holeton \& Randall 1967 a) as well as several other freshwater and marine species (e.g. Hattingh 1967, Yu \& Woo 1987). The pattern of lactate and glucose concentration increases noted in the present work (Figs. $10 \& 11$ ) indicates that low blood $\mathrm{O}_{2}$ concentrations likely triggered anaerobic metabolism in the trout treated with Chaetoceros concavicornis. Boutillier et al. (1988) noted that when environmental $\mathrm{O}_{2}$ concentrations fell below $50 \mathrm{~mm} \mathrm{Hg}$ plasma lactate levels of rainbow trout rose as increased hypoxia boosted the rate of anaerobic metabolism. In the experiments reported here, the concentration of oxygen exceeded $50 \mathrm{~mm} \mathrm{Hg}$ in the water. However, this gas was unable to pass the secondary lamellar cells at rates commensurate with the maintenance of aerobic 
conditions in the arterial blood, allowing the $\mathrm{O}_{2}$ concentrations to fall far below the concentrations which one would expect with this high concentration of $\mathrm{O}_{2}$ in the water.

The data presented here clearly indicate that the barbed spines of the harmful diatom Chaetoceros concavicornis damage the physical integrity of the respiratory epithelium of rainbow trout, and by extension, that of other salmonids. The trout responds to this physical impairment of gill tissue by producing excessive amounts of mucus. The accumulation of this mucus on and between the secondary lamellae inhibits the gill functions of $\mathrm{O}_{2}$ diffusion (and probably metabolic waste products release.) The hypoxic conditions which result within the fish then cause a cascade of events, including anaerobic metabolism, as the trout attempts to compensate for loss of arterial blood $\mathrm{O}_{2}$. In the experiments described here, impairment of trout respiration was not sufficiently great to cause mortality of the fish within the $72 \mathrm{~h}$ of the $C$. concavicornis treatment. However, most of the parameters assayed showed significant increases (or decreases) with time. Had $C$. concavicornis treatment of the fish proceeded beyond $72 \mathrm{~h}$, mortality of the fish would likely have occurred due to this harmful diatom.

Acknowledgements. This research was funded by a Natural Sciences and Engineering Research Council of Canada grant to L. J. A. We thank Michael Axelsson and Ling Hong for aid in several of the assays used in the experiments. We also thank Dr D. Randall for a critical review of the manuscript.

\section{LITERATURE CITED}

Albright, L. J., Johnson, S., Yousif, A. (in press). Temporal and spatial distribution of the harmful diatoms Chaetoceros concavicornis and Chaetoceros convolutus along the British Columbia coast. Can. J. Fish. Aquat. Sci.

Bell, G. R. (1961). Penetration of spines from a marine diatom into the gill tissues of lingcod (Ophiodon elongatus) Nature, Lond. 192: 279-280.

Bell, G. R., Griffioen, W., Kennedy, O. (1974). Mortalities of pen-reared salmon associated with blooms of marine algae. Northwest Fish. Cult. Conf, Seattle, WA, p. 58-60

Boutillier, R. G., Dobson, G., Hoeger, U., Randall, D. J. (1988). Acute exposure to graded levels of hypoxia in rainbow trout (Salmo gairdneri): metabolic and respiratory adaptions. Respir. Physiol. 71: 69-82

Brett, J. R., Griffioen, W., Solmie, A. (1978). The 1977 crop of salmon reared on the Pacific Biological Station experimental fishfarm. Fish. mar. Serv. Tech. Rep. 845: 1-17

Claireaux, G., Thomas, S., Fievet, B., Motais, R. (1988). Adaptive respiratory responses of trout to acute hypoxia. II Blood oxygen carrying properties during hypoxia. Respir. Physiol. 74: 91-98

Cossins, A. R., Richardson, P. A. (1985). Adrenalin-induced $\mathrm{Na}^{+} / \mathrm{H}^{+}$exchange in trout erythrocytes and its effects upon oxygen-carrying capacity. J. Exp. Biol. 118: 229-246

Fievet, B., Claireaux, G., Thomas, S., Motais, R. (1988). Adaptive respiratory responses of trout to acute hypoxia. III. Ion movements and $\mathrm{pH}$ changes in the red blood cell. Respir. Physiol. 74: 99-114

Gaines, G., Taylor, F. J. R. (1986). A mariculturist's guide to potentially harmful marine phytoplankton of the northwest Pacific coast. Marine Resource Section, Fisheries Branch, British Columbia Ministry of Environments, Victoria

Guyton, A. C. (1981). The coronary circulation and ischemic heart disease. In: The textbook of medical physiology. Saunders, Toronto, p. 123-128

Hattingh, J. (1967). Blood sugar as an indicator of stress in the freshwater fish, Labeo capensis (Smith). J. Fish Biol. 10: 191-195

Holeton, G. F., Randall, D. J. (1967a). The effect of hypoxia upon the partial pressure of gases in the blood and water afferent and efferent to the gills of rainbow trout. J. exp. Biol. 46: 317-327

Holeton, G. F., Randall, D. J. (1967b). Changes in blood pressure in the rainbow trout during hypoxia. J. exp. Biol. 46: $297-305$

Hughes, G. M. (1981). Effects of low oxygen and pollution on the respiratory systems of fish. In: Fishering, A. D. (ed.) Stress and fish. Academic Press, New York, p. 121-146.

Ishimatsu, A., Iwama, G. K., Heisler, N. (1988). In vivo analysis of cardiac output between systemic and central venous sinus circuits in rainbow trout: a new approach using chronic cannulation of the branchial vein. J. exp. Biol. 137: 75-88

Johansen, K., Hanson, D. (1967). Hepatic vein sphincters in elasmobrachs and their significance in controlling hepatic blood flow. J. exp. Biol. 46: 195-203

Kennedy, W. A., Shoop, C. T., Griffioen, W., Solmie, A. (1976). The 1974 crop of salmon reared on the Pacific Biological Station experimental fishfarm. Fish. Mar Serv. Tech. Rep. No. 612. Resource Service, Pacific Biological Station, Nanaimo

Maren, T. H., Embrey, R., Broder, L. E. (1968). The excretion of drugs across the gill of the digfish, Squalus acanthias. Comp. Biochem. Physiol. 26: 853-864

Milligan, C. L., Wood, C. M. (1986). Tissue intracellular acidbase status and the fate of lactate after exhaustive exercise in the rainbow trout. J. exp. Biol. 123: 123-144

Moran, F., Kettel, L. J., Cugell, D. W. (1966). Measurement of blood $\mathrm{PO}_{2}$ with the microcathode electrode. J. appl. Physiol. 21: 725-728

Murad, A., Houston, A. H., Samson, L. (1990). Haematological response to reduced oxygen-carrying capacity: increased temperature and hypoxia in goldfish, Carassius auratus $\mathrm{L}$. J. Fish Biol. 36: 289-305

Nikinmaa, M. (1982). Effects of adrenalin on red cell volume and concentration gradient of protons across the red cell membrane in the rainbow trout. Molec. Physiol. 2: 287-297

Nikinmaa, M., Huestis, W. H. (1984). Adrenergic swelling of nucleated erythrocyres: cellular mechanisms in a bird, domestic goose, and two teleosts, striped bass and rainbow trout. J. exp. Biol. 122: 139-148

Ostroumova, I. N. (1964). Condition of trout blood at adaption to different oxygen and salt conditions of water. Izv. Vses. Nauchno-izsled. Inst. Ozern. Rechn. Ryb. Khoz. 58: 27-36

Randall, D. (1982). The control of respiration and circulation in fish during exercise and hypoxia. J. exp. Biol. 100: 275-288

Randall, D. J., Jones, D. R. (1973). The effect of deafferentation of the pseudobranch on the respiratory response to hypoxia and hyperoxia in the trout (Salmo gaidneri). Respir. Physiol. 17: 291-301

Saunders, R. L. (1962). The irrigation of the gills of fishes. II. Efficiency of oxygen uptake in relation to respiratory flow. activity and concentrations of oxygen and carbon dioxide. Can. J. Zool. 40: 817-862 
Smith, F. M., Jones, D. R. (1982). The effect of changes in blood oxygen-carrying capacity on ventilation volume in the rainbow trout (Salmo gairdneri). J. exp. Biol. 97 : 325-334

Soivio, A., Nyholm, K., Westman, K. (1975). A technique for repeated sampling of the blood in individual resting fish. J. exp. Biol. 62: 207-217

Stevens, E. D. (1968). The effect of exercise on the distribution of blood to various organs in rainbow trout. Comp. Biochem. Physiol. 9: 197-200

Responsible Subject Editor: O. Kinne, Oldendorf/Luhe, Germany
Tetens, V., Lykkeboe, G. (1985). Acute exposure of rainbow trout to mild and deep hypoxia: $\mathrm{O}_{2}$ affinity and $\mathrm{O}_{2}$ capacitance of arterial blood. Respir. Physiol. 61: 221-235.

Thomas, S., Hughes, G. M. (1982). A study of the effects of hypoxia on acid-base status of rainbow trout blood using an extracorporeal blood circulation. Respir. Physiol. 49 371-382

Yu, K. L., Woo, N. Y. S. (1987). Metabolic adjustments of an air-breathing teleost, Channa maculata, to acute and prolonged exposure to hypoxic water. J. Fish Biol. 31: 165-175

Manuscript first received: February 26, 1992 Revised version accepted: August 10, 1992 